\title{
The Consequences of Abandoning African Tradition \\ Represented in Credo Mutwa's Play uNosilimela
}

\author{
A Paper \\ Submitted by \\ Howayda Hassan Ali El Sherif \\ Assistant Lecturer- English Department \\ Faculty of Women-Ain Shams University
}

Under the supervision of

Dr. Mona Anwar Wahsh

Associate Professor of English Literature

Faculty of Women

Ain Shams University
Dr. Shahira Fikry Kelesh

Lecturer of English Literature

Faculty of Women

Ain Shams University 
Lecturer of English Literature

Faculty of Women

Ain Shams University

\begin{abstract}
This research paper explores the impact of the European contact on African tradition in a colonial context. It focuses on the hazards of abandoning tradition and substituting it with the colonizer's alien culture. This is examined through a postcolonial reading of uNosilimela (1973) by the South African playwright Credo Mutwa (1921- ).This reading is guided by the works of Frantz Fanon (1925-1961) as a frame of reference. In the play, uNosilimela goes through a journey which represents the Africans' relationship with their tradition before and after the colonial impact. uNosilimela's abandoning of her African tradition exposes her to severe suffering. However, her final self-realization leads to a reunion with tradition. Therefore, the play's core is Mutwa's call for the Africans to reunite with their tradition and to defend it against the colonizer's attempts to alienate them from their identity.
\end{abstract}


The objective of this paper is to show the danger caused by abandoning African tradition. This is explained through uNosilimela's journey to selfrealization. The paper is divided into two sections. The first section deals with the term tradition and how it is applicable to Africa's reverence to the past. The researcher then surveys the threats that African tradition was exposed to by the European colonialism. This leads the way to the second section in which uNosilimela is being discussed. In the play, Mutwa traces the Africans' fluctuating relationship with tradition through uNosilimela, the play's heroine. In her journey to self -realization, Mutwa presents a clear picture about the difference between traditional Africa and the one polluted by Europe's colonial impact.

The research paper's frame of reference depends on the works of Frantz Fanon (1925-1961). His books The Wretched of the Earth (1963), Black Skin, White Masks (1967) and Toward the African Revolution (1988) are essential for revealing the cultural and psychological effects of colonialism on the Africans and their tradition. Several questions are answered throughout the paper: What is the importance of preserving African tradition? How do the colonizers try to uproot Africans from their identity? How does uNosilimela's abandoning of tradition lead to her suffering? How does uNosilimela reach her self-realization? 


\section{African Tradition Before and After Colonialism}

Tradition is derived from the Latin word "tradere" which means to "deliver" or "hand over" (Fornas 22). Therefore, tradition "hands something over through time, from one generation to another" (22). This shows that it is the essential link between the ancestors who represent the past and their descendants who represent the present. Together, they complete the process of transmission in which "a set of beliefs, customs, knowhow, attitudes, psychological mindsets, etc." (Diop 223) secure the unified cultural identity that the members of a certain nation usually share.

From this perspective, African societies are traditional as they adopt specific "patterns, customs, beliefs and rituals inherited from the past and orally transmitted through generations ...." (Omeje and Kwaja 95). Among these traditional features that give Africa its specificity are the Africans' strong belief in their traditional religion, their sense of solidarity as well as their loyalty to the tribe.

African traditional religion can be defined as the "religious beliefs and practices of the Africans. It is the ... heritage from the past . . . which connects the past with the present and the present with eternity" (Awolau 1). In this deep rooted religion, the Africans' reverence to the past becomes clear in the respect and honour they give to their ancestors. While they are alive, the ancestors are regarded as "the guardians of the existing social order, the custodians of tradition ..." (Schapera 30). After their death, they become the "intermediaries" between their descendants and God (Mangany and Buitendag 1). 
Another remarkable aspect of the African traditional society is the concept of solidarity which forms the bases of the Africans' lives. In this collaborative society, Africans are taught that they are all members of a big family which is the tribe. Based on this strong sense of belonging, the members of the tribe provide "love, attention, and care" for each other (Some`301). This means that under this communal system, no one has to suffer from the shortage of "food, shelter or love as long as there is a relative or tribal brother with anything at all to share" (Lamb 33).

Africa's unique traditional identity remained intact until its contact with Europe through colonialism. It was an abusive relationship in which Europe used its military and economic power to declare its superiority over Africa as one of "those pre-modern societies and cultures that were 'locked' in the past ..." (Ashcroft, et al. 145). In their claims, European powers were mainly pushed by their need for "sources of raw materials" (Patke 7) as well as "markets supporting the economic expansion" that they were going through at that time (7). This qualified Africa to become the perfect candidate for colonial exploitation. However, this exploitation needed a cover which was labeled, the "civilizing mission" (Mignolo 14).

This sacred mission revolved around imposing "Western civilization by celebrating its achievements" (2-3) in addition to "saving the souls through conversion to Christianity" (14). Under this moralistic cover, Europe embarked on its brutal exploitation to Africa's economic "resources in the form of minerals, agricultural produce and land" (Diop 227).

European colonialism to Africa was not only destructive in its military form but also in its cultural one. This form of "cultural imperialism" (Iweriebor 469) was based on substituting the African traditional culture, language and 
religion which were considered inferior to those of superior Europe. The result of this cultural uprooting was that many Africans began to suffer from "cultural estrangement" (Fanon, Wretched 210). Fanon believes that through this process:

Colonialism is not satisfied merely with holding a people in its grip and emptying the native's brain of all form and content. By a kind of perverted logic, it turns to the past of the oppressed people, and distorts, disfigures, and destroys it. (210)

This highly destructive role was carried out by the European missionaries in Africa. They were Europe's colonial agents who began to erase Africa's traditional identity and religion by replacing them with those of the colonizers. This was done through education and Christianity.

Regarding education, it was a necessity to breed a new generation of African youth who were to become followers to "the values of western society . . ." (Khapoya 156). Moreover, it was a tool for increasing the number of "African workers (both semiskilled and clerical) without necessarily empowering them sufficiently to challenge colonial rule" (156).

As for Christianity, it was wickedly turned from a heavenly religion that was based on "love and equality between men" (Ngugi 31) into a colonial religion which preached "inequality ... and the consequent subjugation of the black race by the white race" (31). Eventually, many Africans became victims of this cultural sabotage. They began to believe that "mimicking and assimilating 
values set before them by missionaries" (Sindima 124) would make them equal to their superior oppressors. Consequently, they "turned their backs on their own traditions, calling them heathen practices, superstitions, and work of the devil" (124).

European colonialism knew how African traditional religion was not only Africa's faith, but also its identity. Therefore, colonialism used its brain-washed Africans in persuading their brothers to convert to Christianity and forsake "the religion of their forefathers" (Bascom and Herskovits 3). Nevertheless, many Africans did not respond to these calls and continued to believe in "African deities, the homage to the ancestors, and the recourse to divination, magic, and other rituals"(3).

African tradition was not only subjected to the assaults of Europe's colonial religion, it was also attacked by a series of European ills which were alien to the African traditional society. The most prominent were urbanization and individualism. According to Nugent, urbanization was related to "the city, with consumption for its own sake and with individual self-expression" (127). This contrasted with the African traditional societies which were "associated with the countryside, with ritual practices and with communal norms ..." (127).

Though the difference was obvious, colonialism succeeded in creating urban centers all over Africa. This encouraged many Africans to forsake their rural tribal life and to migrate to the cities in search for money (Dubb 444). They were easily lured by the big cities' "modern amenities like electric lighting, large stores and shops, cinemas, bars and dance halls" (Little 11) which separated them from "the bush enclosing their village" (11). This physical and mental 
separateness from the tribe led to the growth of a strong sense of individualism. The result was "fragmenting community life and making each person think in terms only of his or her own interests without any commitment to a shared social life that characterizes the traditional society" (Gyekye 276).

As a result of these colonial influences and their impact on the African traditional identity, many voices began to call for a return to African tradition. Among these voices was Frantz Fanon who believed that the return to tradition was the only way to cure the Africans' sense of inferiority that was caused by colonialism. In Black Skin, White Masks, Fanon wrote that the more the African embraced his tradition, the more he acknowledged that the "white man was wrong, I was not a primitive, not even a half-man, I belonged to a race that had already been working in gold and silver two thousand years ago" (130).

Fanon even spoke about the African intellectuals who re-embraced their tradition and wished that others would follow them:

... the native intellectuals ... decided to back further and to delve deeper down; and let us make no mistake, it was with the greatest delight that they discovered that there was nothing to be ashamed of in the past, but rather dignity, glory, and solemnity. (Wretched 210)

These words typically apply to Credo Mutwa who uses his work, uNosilimela as a means for reminding the Africans of the importance of sticking to their tradition in a world infested by destructive colonial influences. In 
Mutwa's play, uNosilimela is not only the heroine, but she is also a symbol of Africa. She goes through a journey which begins with her alienation from tradition and ends with re-embracing it.

\section{II. uNosilimela's Reaction to Tradition from Rejection to Reconciliation}

The first stage in uNosilimela's journey which the paper discusses is her traditional environment. This is intended to show how her sense of power and security later disappears when she is banished from her home. The second stage concentrates on uNosilimela's deterioration after turning against tradition. She becomes vulnerable to betrayal, injustice, racist Christianity and death threats by murderers. This is contrasted with the positive aspects that tribal tradition offers including fidelity, justice, spirituality of African traditional religion and safety of family ties. The last stage represents the end of uNosilimela's journey. In it, she re-embraces her traditional identity when she discovers tradition's power in ending her suffering.

\section{1. uNosilimela's Sacred Birth and Early Life within Tradition}

uNosilimela is the amaQhashi's princess. She is half human from her father, king Magadlemzini's side and half goddess from her mother Kimamireva, who is the "princess of the stars" (Mutwa, uNosilimela 16). When Magadlemzini and Kimamireva got married, Mangothobani, the high diviner, predicted that the fruit of this marriage will be a child who "will one day save the amaQhashi from destruction, a child whose greatness will be the talk of the future ages" (18).

After uNosilimela was born, she was named after "the Silimela constellation" (18) which her mother used to watch every night when she was 
pregnant. When Kimamireva died during childbirth, the amaQhashi were summoned to declare uNosilimela as "a goddess who was to be worshiped and to whom marriage and love were to be denied" (19). This explains the ' $u$ ' in her name which the Zulu usually use for praise to a sacred figure (Mzolo 214).

uNosilimela grows up to become a rebellious young woman who defies all rules set up for her especially by tradition. She begins to gradually violate traditional rules until she finally declares her rejection to it. This drives her father to call her a "child of rebellion!" (Mutwa, uNosilimela 20) .uNosilimela's first sign of her refusal to her sacred position in tradition appears in her sister's wedding. She is shown lamenting her destiny saying, "[o] god, why god, why am I denied love? ... Am I not a woman? All my sisters are married but I'm left behind like a broom. Why, god, why? "(20).

uNosilimela's envious feelings towards her brothers and sisters who can live a normal life, push her to make love to a young man called Jabulani. With this act, uNosilimela defiles her divinity by involving in a physical relationship. The shame that she brings to herself increases even more when she later suffers from a miscarriage. As a result of her hideous acts, her father, Magadlemzini gives her the punishment she deserves according to tradition. He tells her:

... it is the law of your forefathers that if a child has done what you have just done, her father must not talk to her for three months. From this moment I shall no longer call you to my side nor eat the food you give me nor drink the water you offer me. I shall treat you as one dead. Sengikhulumile! [ I 
Here, Mutwa shows how punishment is applied in traditional societies. There is no difference between people because of their status or origins. All are equal when it comes to abiding to traditional laws. The same applies to uNosilimela who gets to be punished by her father. This traditional justice is contrasted with the European injustice which uNosilimela later experiences during her exile.

In spite of all these hardships, uNosilimela continues her defiance to tradition. The climax of her rebellion appears when Namdozolwana, her stepmother, proudly confesses that she has killed Jabulani to avenge uNosilimela's honour. As a result of this confession uNosilimela "strikes the older woman an open-handed blow with the back of her hand" (25). With this incident, uNosilimela declares her complete abandoning to tradition including her respect for one of the tribe's elders who represents traditional authority.

The humiliation that uNosilimela directs to tradition becomes so severe to the extent that the Earth Mother, uNamkhumbulwana descends to announce that the "hand that strikes the mother is cursed throughout the land!" (25). Inspite of his love to his daughter, king Magadlemzini honors the gods by declaring uNosilimela's exile saying:

My child, the ancient law of your fathers says that if a child strikes its parent that child shall be exiled from the land of its people for fifteen years.... And, when your period of exile is over, you will 
find me waiting here in the Great Place of your fathers, waiting to welcome you with open arms once more. I have spoken. (25)

In African tradition, exile is usually given as a punishment to the most horrific crimes. This stems from the fact that exile "ruins both body and soul" (Nnam 71). However, this punishment for uNosilimela becomes her chance to escape from the prison of her people's tradition. Therefore she celebrates her freedom saying:

A dark cloud of shame hangs over my head. [she brightens up] But it has bright silver edges! I am now free, free to live, to learn and free to love! Farewell, tribal stuffiness and restriction! And welcome life and endless joy! (Mutwa, uNosilimela 26)

Fanon writes about a similar situation to that of uNosilimela when the black man dreams of the paradise that Europe has established beyond his place of belonging:

There is a psychological phenomenon that consists in the belief that the world will open to the extent to which frontiers are broken down. Imprisoned on his island, lost in an atmosphere that offers not the slightest outlet, the Negro breathes in this appeal of Europe like pure air. 
Nevertheless, this illusion soon disappears when he is subjected to the racist behavior of the colonizer that does not change by changing his place. The situation is the same for uNosilimela who begins her journey of suffering the moment she leaves her land where tradition dominates.

\section{2. uNosilimela's Deterioration in Exile}

This part traces uNosilimela's suffering outside the protection of her traditional environment. Here, the focus is on uNosilimela's relapse which increases the more she detaches herself from her traditional identity. This is crucial in contrasting the values of traditional societies with the corruption that exists beyond them.

\section{- Marriage outside the Sacredness of Tradition}

uNosilimela experiences deceit in the most sacred relation in life which is marriage. This occurs when she meets Alpheus Mafuza and marries him. After moving to his house, Alpheus leaves to Johannesburg and abandons her for "a rich man's daughter" (Mutwa, uNosilimela 27). To secure his new marriage, Alpheus plots with his mother to get rid of uNosilimela. Therefore, she accuses uNosilimela of witchcraft and sends her to court for trial.

This is a strong evidence of how marriage is viewed in a society alienated from tradition. Marriage is no longer a sacred relationship, but rather a materialistic one. This is highly contrasted with the sacred value of marriage in 
African tradition which is shown in the marriage of uNosilimela's sister. Mutwa describes the ceremony of her sister's marriage as a communal celebration in which all the amaQhashi participate. When Magadlemzini presents his daughter to the groom, he makes him swear by the gods that he will "love and cherish my child, Bagangile, to the end of your days ..." (19). In this traditional context, marriage becomes a sacred bond which is based on trust rather than deceit. Unfortunately, uNosilimela realizes the difference after it is too late.

\section{- The Injustice of Modern Courts}

uNosilimela witnesses another form of corruption when she is sent to court by her mother in-law. Though it is supposed to be a place where justice is given to those who deserve it, the court is headed by a drunken judge who cannot even stand on his feet. Without inspecting the unjust accusation against uNosilimela, he ends the trial considering her guilty. He even begins to sexually harass uNosilimela telling her, "you would make a delicious breakfast. . . . I want you in bed one day, uyandiva ke?" (28).

This scene is the exact opposite of the traditional trial which ruled to banish uNosilimela. In it, the king's verdict is against his own daughter. This proves that in African traditional law, justice prevails. The verdict is also merciful as the exile is for a specific time and once it is finished, uNosilimela can go back. As for the law outside tradition, it is represented by lustful drunken men. In such conditions, uNosilimela begins to miss the safety of her land where she was protected by both her people as well as her sacred status which was given to her by tradition. 


\section{- The Misrepresentation of Christianity}

In exile, uNosilimela is not only estranged from her tribal bonds but also her traditional religion. This occurs when she is introduced to Christianity. In this episode, Mutwa criticizes the role of Western Christianity in turning the African against his traditional religion and consequently his identity. This is clear through the character of Sister Veronica. She is a black nun who teaches uNosilimela how to read and write. In return, Sister Veronica converts her to Christianity and therefore becomes uNosilimela's link to the Europeans' religion.

Sister Veronica symbolizes the brain washed Africans who fully accept the colonizers' subjugating views and even spread it among their people. This appears when she insists that uNosilimela must be baptized or else she will be condemned to Hell. She takes uNosilimela to church and shows her how the Bible portrays the white Adam and Eve in the presence of a black Satan. Nevertheless, uNosilimela refuses to believe that "all the great chiefs of the past who died before the coming of Christianity"(32) have gone to Hell. She even draws Sister Veronica's attention that if Adam and Eve were white, "where did we the black people originate?" (33).

uNosilimela's inquiries begin to reveal the shallowness of Europe's racist Christianity. In this incident, the colonial role of the missionaries becomes clear in using Christianity as a weapon to turn Africans against their culture. According to Fanon:

The customs of the colonized people, their traditions, their myths ... are the very sign 
of that poverty of spirit... That is why we must put the DDT which destroys parasites, the bearers of disease, on the same level as the Christian religion which wages war on embryonic heresies and instincts, and on evil as yet unborn. (Wretched 42)

It is noticeable how uNosilimela fails to understand the kind of Christianity that Sister Veronica offers her. This indicates how African traditional religion is an inseparable part of the African identity. However, it is the price that they must pay to acquire missionary education.

\section{- uNosilimela in Johannesburg}

The most difficult stage in uNosilimela's journey is when she reaches Johannesburg. In this part, Mutwa portrays Johannesburg as the center of violence and corruption. It is the place where organized crimes prevail through gangs, criminals and where immoral activities are the norm through the shebeens. In the middle of this poisonous atmosphere, uNosilimela laments the purity of the rural life that she was living in among her people.

Through Johannesburg, Mutwa directs a sever attack to European urbanity which changed the nature of the traditional African societies. During the colonial presence, many Africans turned to the big cities searching for better economic opportunities that were not available in their small villages. The result of this migration was the formation of crowded slums where poverty and unemployment prevailed. In this alien setting, the rural Africans found 
themselves isolated from the tribal bonds that gave them solidarity. They became brutal to each other as they were competing for material gains. Fanon describes a typical African urban setting saying:

The town ... is a place of ill fame, peopled by men of evil repute. They are born there, it matters little where or how; they die there, it matters not where, nor how. It is a world without spaciousness; men live there on top of each other, and their huts are built one on top of the other. (Wretched 39)

In Johannesburg, uNosilimela meets Mamoloi, the owner of a shebeen. The moment she sees uNosilimila, Mamoloi decides to take advantage of her beauty by making "money out of her" (Mutwa, uNosilimela 36). This reflects the corruption of this society in which humans are regarded as commodities who can be sold to the highest bidder.

In the city, Mutwa writes about another form of violence, but this time it is against oneself. This is in the form of assimilation. It occurs when a

racialized social group tries to imitate the oppressor and thereby to deracialize itself. The "inferior race" denies itself as a different race. It shares with the "superior race" the convictions, 
doctrines, and other attitudes concerning it.

(Fanon, Toward the African Revolution 38)

Mutwa represents assimilation through the character of Alpheus Mafuza, uNosilimela's husband. He reappears in the play but this time under the name of Mr. Jackson Makudula. He visits Mamoloi's shebeen in the white man's clothes accompanied by his new wealthy wife. Alpheus's new name and clothes are a symbol of his betrayal not only to uNosilimela who represents tradition but also to himself. He gives up his own sense of belonging for a subjugating identity which is based on materialism and fake appearances. People like Alpheus are described by Fanon in his book Black Skin, White Masks as follows:

For him there is only one way out, and it leads into the white world ... his concern with being powerful like the white man, his determined effort to acquire protective quatities that is, the proportion of being or having that enters into the composition of an ego.... From black to white is the

course of mutation. One is white as one is rich, as one is beautiful, as one is intelligent. (51 - 52)

Alpheus's selfishness reaches its extreme when he sees uNosilimela in the shebeen and ignores her. He prefers his new status to his former wife and therefore he refuses to save her from what she is in. Even when uNosilimela recognizes him, he insults her saying: 
You see, if you're man-crazy, just go to

Dube hostel: You'll find plenty men there.

[furtively he takes out his wallet and offers

Nosilimela some banknotes] .... Go

and bark at somebody else, baby.

(Mutwa, uNosilimela 44)

His wickedness does not stop at this point. He realizes that uNosilimela's presence in Johannesburg will jeopardize his new marriage. Therefore, he hires a murderer to get rid of her. It is clear that Alpheus is seeking to secure his individual interest by any means. This strong sense of individualism is seen by Fanon as a direct result to assimilation. He explains that the African who submerges himself into the oppressor's culture "has clothed his aggressiveness in his ... desire to assimilate ... . He has used his aggressiveness to serve his own individual interests" (Wretched 60).

\section{3. uNosilimela's Reconciliation with Tradition}

Fearing for her life, uNosilimela escapes to the northern part of Transvaal. In her loneliness and fear, uNosilimela pleads for deliverance. However, the religious perplexity that she experiences through her journey makes her incapable of choosing a god to direct her prayers to. At that moment, uMvelinqangi, the Earth Mother's son appears.

Through this confrontation, uNosilimela finally embraces her previously rejected tradition. She realizes the authenticity of African tradition which she 
was not able to find in European culture. uMvelinqangi teaches her about Africa's belief in a universal God who does not belong to a certain race or colour. He even asserts that Africa was the cradle of the entire humanity as well as the place where "Man first discovered God" (Mutwa, uNosilimela 51). uMvelinqangi ends his lesson to uNosilimela by pointing to the reason behind Africa's deterioration which is the advent of the white man with his new culture and religion. This represents the core of the play. He tells uNosilimela :

[...] your people always held the belief that a race is only as great as the gods it believes in and when they saw the guns of the whiteman, they wrongly assumed therefore that his religion was different and superior to theirs ... There lay the tragedy. (53)

In return for giving uNosilimela the knowledge that she needs, uMvelinqangi takes away her eyesight leaving her blind. Inspite of her pain, uNosilimela shows her acceptance of uMvelinqangi's verdict. She reaches a stage of self-realization and states that "[a]fter what I have seen, after the miracle my eyes have beheld, I seek not to look upon this evil world again"(53). Therefore, uNosilimela's blindness is significant. In losing her eyesight, she gains her insight about the uniqueness of her traditional identity as well as her role in securing its continuity to the future generations of the amaQhashi.

With uMvelinqangi's punishment, uNosilimela ends her exile and returns home. On her return, uNosilimela is warmly welcomed by her father and the entire tribe. The amaQhashi's celebrations become symbolic of uNosilimela's readoption of her role as their savior. When a destructive series of "bombs and explosions are heard" (58), uNosilimela reaches full realization of the role 
prescribed to her by tradition and which was stated many years back in Mangothobani's prophecy. As the fire spreads throughout the place, uNosilimela directs the amaQhashi to the Earth Mother's cave where they take shelter. The fire consumes everything around them to indicate that all what is corrupt is vulnerable to destruction. As for the amaQhashi, they are saved because of their belief in their tradition.

The play ends with a futuristic scene which shows the amaQhashi's descendants celebrating the historical day when their ancestors were saved from the destructive fire five hundred years back. This optimistic scene reflects Mutwa's vision that the day Africa regains its tradition, peace and prosperity will prevail. However, re-embracing tradition can only occur when Africa sheds away the destructive influence of the West. According to Mutwa:

The only thing that can save us is to tell the foreigners openly that we do not wish to have their alien creeds, dogmas, beliefs .... The sons of Africa must let the world know that we can well do without civilisation if this means that we have to throw our own culture, beliefs and way of life overboard .... You must bring out the many things hidden in your villages - things that whisper of Africa's not - yet - forgotten past. (Indaba, My Children 692 - 693) 


\section{Conclusion}

To sum up, tradition is part and parcel of one's identity. It is the bridge that connects the past to the present in order to secure the future. Based on that function, tradition has been the core of the African identity which has given it its uniqueness. However, this distinct identity has been threatened by Europe's intervention through colonialism. This craving for Africa's riches has been disguised as a noble cause which aimed at civilizing Africa. The mission of saving the Africans from their primitiveness has turned into an act of sabotaging their sense of belonging to their traditional culture and religion. Consequently, this has led to alienating the Africans from their own identity replacing it with that of their oppressors.

From that perspective, Mutwa has written uNosilimela as a warning against the destructive results of forsaking African tradition. He has focused on uNosilimela who has symbolized Africa's estrangement in a world governed by colonial norms. Mutwa has traced uNosilimela's journey including her life within traditional rules. Then he has shifted to her revolt against tradition. There, he has concentrated on the colonial ills that swept the African society. Mutwa has ended the play by uNosilimela's reconciliation with tradition which consequently has saved her people from the destruction which has been created by colonialism. Mutwa's play has become a plea for re-embracing African tradition which he believes to be Africa's weapon against the colonizer's attempts to annihilate the African identity.

Thus, the research questions that have been raised at the beginning of the paper have been answered through tracing uNosilimela's journey to selfrealization. Mutwa's message therefore, has centered on raising the Africans' 
awareness about the importance of preserving their tradition as the strongest defense against the colonizers' wicked strategies to uproot them.

\section{Works Cited}

Ashcroft, Bill, et al. Post-Colonial Studies: The Key Concepts. Routledge, 2000.

Awolau, J.O. "What is African Traditional Religion?" Studies in Comparative Religion, vol.10, no.2, Spring 1976, pp. 1-10. World Wisdom. Accessed 6 June 2016.

Bascom, William R. and Melville J. Herskovits, editors. Continuity and Change in African Cultures. U of Chicago P, 1998.

Diop, Samba. "African Elites and Their Post-Colonial Legacy: Cultural, Political and Economic Discontent by Way of Literature." African Development, vol. xxvii, no.4, 2012, pp. 221-235. CODESRIA Accessed 6 June 2016.

Dubb, Allie A. "The Impact of the City." The Bantu- Speaking Peoples of Southern Africa, edited by W.D. Hammond-Took, Routledge and Kegan Paul, 1974, pp. 441-472.

Fanon, Frantz. Black Skin, White Masks. Translated by Charles Lam Markmann, Grove Press, 1967.

---. The Wretched of the Earth. Translated by Constance Farrington, Grove Press, 1963. 
---. Toward the African Revolution: Political Essays. Translated by Haakon Chevalier, Grove Press, 1988.

Fornas, Johan. Cultural Theory and Late Modernity. SAGE Publications, 1995.

Gyekye, Kwame. Tradition and Modernity: Philosophical Reflections on the African Experience. Oxford UP, 1997.

Iweriebor, Ehiedu E. G. "The Psychology of Colonialism." The End of Colonial Rule: Nationalism and Decolonization, edited by Toyin Falola, vol. 4, Carolina Academic Press, 2000, pp. 465-482. Africa Series.

Khapoya, Vincent B. The African Experience: An Introduction. $3^{\text {rd }}$ ed., Pearson Education, 2010.

Lamb, David. The Africans. Random House, 1982.

Little, Kenneth. West African Urbanization: A Study of Voluntary Associations in Social Change. Cambridge UP, 1965.

Mangany, Jele S. and Johan Buitendag. "A Critical Analysis on African Traditional Religion and the Trinity." Theological Studies, vol. 69, no. 1, July 2013, pp.1-13. AOSIS. Accessed 18 April 2016.

Mignolo, Walter D. The Darker Side of Western Modernity: Global Futures, Decolonial Options. Duke UP, 2011.

URL: http:// www. jstor.org/ stable/ 259800. 
Mutwa, Credo Vusamazulu. Indaba, My Children: African Tribal History, Legends, Customs and Religious Beliefs. Canongate Books,1998.

---. "uNosilimela." South African People's Plays, edited by Robert Mshengu Kavanagh, Heinemann Educational Books, 1981, pp. 1- 61.

Mzolo, Douglas. "Zulu Clan Praises." Social System and Tradition in Southern Africa, edited by John Argyle and Eleanor Preston-Whyte, Oxford UP,1978, pp. 206-221.

Ngugi wa Thiong'o. Homecoming: Essays on African and Caribbean Literature, Culture and Politics. Heinemann Educational Books, 1972.

Nnam, Nkuzi. Colonial Mentality in Africa. Hamilton Books, 2007.

Nugent, Paul. "Modernity, Tradition and Intoxication: Comparative Lessons from South Africa and West Africa." Oxford Journals, vol. 222, no.9, April 2015, pp.126-145. Oxford Academic. Accessed 8 July 2016.

Omeje, Kenneth and Chris M. A. Kwaja. "Exploring the Conflicts between Traditionalism and Modernity in Postcolonial Africa." The Crises of Postcoloniality in Africa, 2008, pp. 83-101. CODESRIA. Accessed 1 June 2016.

Patke, Rajeev S. Modernist Literature and Postcolonial Studies. Edinburgh UP, 2013.

Schapera, I., editor. Western Civilization and the Natives of South Africa: Studies in Culture Contact. Humanities Press, 1967. 
Sindima, Harvey J. Drums of Redemption: An Introduction to African Christianity. Praeger Publishers, 1999.

Some', Malidoma Patrice. The Healing Wisdom of Africa: Finding Life Purpose through Nature, Ritual, and Community. Penguin Puntnam, 1998.

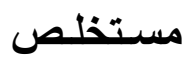

تهدف هذه الورقة البحثية إلى مناقثـة تأثير الإحتلال الأوروبى على الأصـالة الأفريقية متناولة

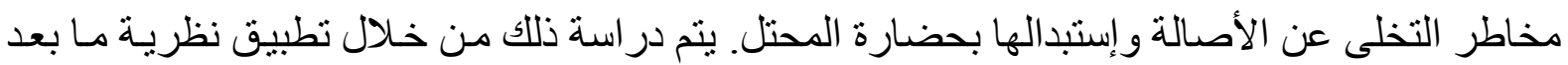

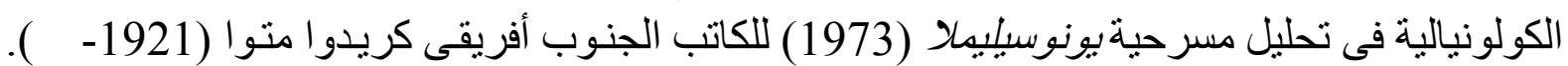

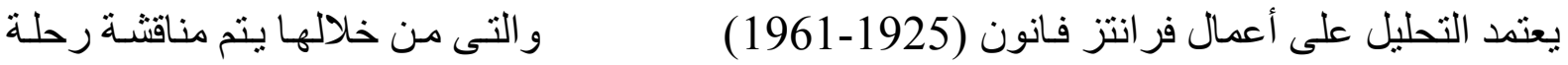

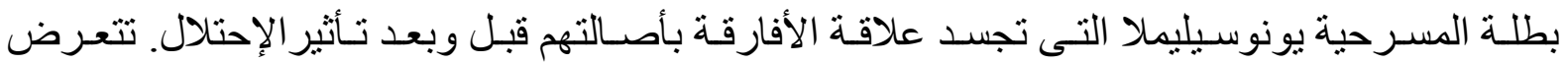

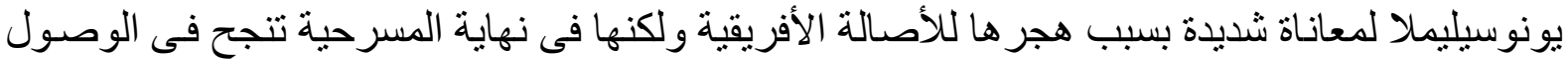

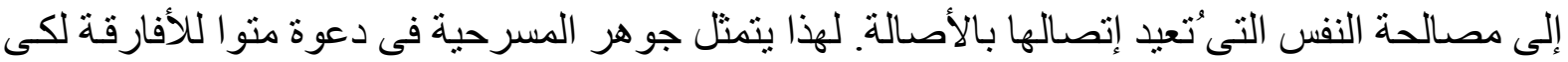

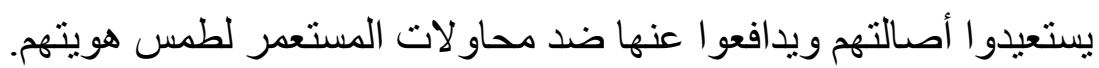

